\title{
PLACE OF THE GOLD STANDARD ISOKINETIC DYNAMOMETER IN PARALYMPIC SPORTS: A SYSTEMATIC REVIEW
}

review paper

(1) University School of Physical Education in Wroclaw

DOI: https://doi.org/10.5114/hm.2021.100319

\section{SHIRKO AHMADI, MARCO CARLOS UCHIDA}

Department of Physical Education, University of Campinas, Campinas, Brazil

\begin{abstract}
Purpose. Isokinetic dynamometers are machines that can supply multiple elements for measuring muscle strength, peak force, power, endurance, and angle of maximal force. The purpose of this study was to run a systematic review to find the quality of evidence in studies evaluating the gold standard isokinetic dynamometer (Biodex) in Paralympic sports.

Methods. The search strategy was defined as: ('Paralympic' OR 'Paralympic sport' OR 'Parasport' OR 'disabled athlete' OR 'athletes with a disability') AND ('strength' OR ‘isokinetic' OR ‘torque' OR 'muscle strength dynamometer' OR 'isokinetic dynamometer' OR 'Biodex'). Four databases were searched: PubMed, Cochrane, ScienceDirect, and Scopus.

Results. From the 981 articles initially found, 10 records were finally included in this systematic review. Five articles were selected as high quality. The Biodex isokinetic dynamometer was introduced about 3 decades ago; still, a small number of papers (10) have been published on applying it in Paralympic sports. We observed different experimental protocols in the included studies. The shortage of standardization in the experimental protocols precludes pooling data for analyses. Conclusions. As the Biodex isokinetic dynamometer is a gold standard, reliable, and valid instrument to measure human joint function, future research should apply it in Paralympic studies.
\end{abstract}

Key words: isokinetic dynamometer, Paralympic sport, place

\section{Introduction}

The isokinetic exercise concept was presented by Perrine in the early 1960s as an integral part of rehabilitation, resistance training, and musculoskeletal testing [1, 2]. Isokinetic exercise, with specified velocity and changeable resistance, made it possible to accommodate the individual strength all over the range of motion [3-5]. The first isokinetic exercise equipment was made in America in 1967 and named CYBEX 1. In 1990, Biodex (Shirley, USA) released Biodex 2000, which (particularly the new versions, such as Biodex System 3 and 4) attracted scientists and other users. Biodex is a computerized machine dynamometer applied for athlete training and isokinetic testing [6].

The Biodex isokinetic dynamometer (BID) is a real update of the first multi-mode computerized global machine dynamometer. The isokinetic image of BID is a popular concept for evaluating and training muscle strength and function [7, 8]. Moreover, it is often used in scientific research to execute measurements $[9,10]$.
It includes a seat on which the athlete is stabilized with belts, a lever that could be located at various joints or angles, and a computer unit with specific software. The whole space needed to utilize the system is $6 \mathrm{~m}^{2}$. It has an electrically controlled servomechanism that could be used with various modes for different modalities and rehabilitation phases. The isokinetic resistance mode gives accelerating or decelerating impact-free [6]. BID can directly record the subsequent parameters: the torque and angular velocity of the lever arm, and time (accuracy of $10 \mathrm{~ms}$ ). Other factors, i.e. force, power, and the parameters that are reported in BID, are calculated indirectly or entered by an operator (e.g. body height, body mass).

In some studies, BID has been presented as a valid and reliable device for the evaluation of human joint function [11-13], and the specific testing protocol and isokinetic velocity has been shown secure for individuals with disability [14]. Some studies have targeted on the physiological response to exercise [15-17], biomechanics $[18,19]$, and upper extremity muscle torque

Correspondence address: Shirko Ahmadi, Department of Physical Education, University of Campinas, Av. Érico Veríssimo, 701, Cidade Universitária 'Zeferino Vaz', Campinas, SP, Brazil, e-mail: shirkooahmadi@yahoo.com

Received: September 16, 2019

Accepted for publication: May 16, 2020

Citation: Ahmadi S, Uchida MC. Place of the gold standard isokinetic dynamometer in paralympic sports: a systematic review. Hum Mov. 2021;22(3):1-10; doi: https://doi.org/10.5114/hm.2021.100319. 
[20-22] of Paralympic athletes. On the other hand, coaches and scientists are extremely concerned about developing ideal training programs to monitor and increase the performance of Paralympic athletes [23].

Paralympic sports, despite their fast improvement in the recent years, still lacks any suitable scientific work to evaluate their therapeutic or functional efficiency [24, 25]. The International Paralympic Committee has encouraged studies based on the scientific principles of athletes' classification in Paralympic sport [26]. We believe that it can identify and find limitations in the case of isokinetic training for Paralympians, and the study of the literature might help this important issue. Presently, several isokinetic dynamometers are available; however, it is BID that has frequently been cited in the literature [27] (although mainly with reference to its application among Olympians rather than Paralympians) [28]. Numerous issues are faced when setting up BID for athletes with a disability that has not been explored in detail. Therefore, this study aimed to review the literature published regarding the gold standard isokinetic dynamometer (BID) applied in Paralympic athletes. This review study provides information that may demonstrate the place of BID in strength testing among athletes with a disability.

\section{Material and methods}

\section{Literature search}

Studies for this review were identified with a systematic search of 4 databases (PubMed, Cochrane, ScienceDirect, and Scopus), alone or in combination. The search was restricted to English-language articles and those published up to March 2019. The following search string was used for a full search strategy: ('Paralympic' OR 'Paralympic sport' OR 'Parasport' OR 'disabled athlete' OR 'athletes with a disability') AND ('strength' OR 'muscle strength dynamometer' OR 'torque' OR 'isokinetic' OR 'isokinetic dynamometer' OR 'Biodex') for all of the databases. Citation tracking was also done by manually seeking the reference lists of included articles and using Google Scholar.

\section{Study selection}

Studies retrieved from the database search were forwarded to EndNote X9. The researchers took out the repeated references and non-original articles (i.e. reviews, editorials, letters to the editor, etc.). Besides, they separately screened the titles and abstracts to recognize studies that would potentially face the eligibility criteria. The full texts of these articles were reviewed and the appropriate papers to the present systematic review were elected. Lastly, the reference list of the chosen studies was checked for identifying further related articles. The consensus-agreement method was used in any case of a difference in the opinions between the 2 reviewers. If a consensus could not be reached, the reviewers reread the article(s) until obtaining a consensus-agreement about it.

\section{Eligibility criteria}

Articles were included in this review study if they met the following criteria:

(a) the full text written in English;

(b) the study participants being elite athletes with a disability playing at the international Paralympic level;

(c) inclusion of participant groups of all ages who competed as Paralympians;

(d) using BID.

Articles were excluded if:

(a) there was no clear indication of whether an athlete was a Paralympian;

(b) another type of isokinetic dynamometer was used instead of BID;

(c) the study did not use empirical data (e.g. a review or commentary).

\section{Quality of the evaluation and risk of bias}

Each study included in this review was separately evaluated for methodological quality and risk of bias by both authors. To the best of our knowledge, there is no specific criterion for a methodological measurement suitable to the goal of this review study. In their systematic review, De Castro et al. [29] composed a new scale by blending some items from QUADAS [30] and a checklist for evaluating the methodological quality of both randomized and non-randomized studies of health care interventions [31], with adaptations. We used this scale for the current review, which included 15 items divided into 3 parts: (i) study participants; (ii) test method and data analysis; and (iii) results (Table 1). Each item was evaluated as 'yes,' 'no,' 'unclear,' or 'not applied'. A high risk of bias (low quality) was assumed if a study obtained 5 or more 'no' or 'unclear' rates; if a study received less than 5 'no' or 'unclear' rates, it was ascribed a low risk of bias (high quality). The quality evaluation of the studies demonstrated that 5 papers presented a low risk of bias (high quality) and the remaining 5 were associated with a high risk of bias (low quality). 


\section{Data extraction}

The following information was extracted from the included articles: publishing year, country of origin, number of participants, age, sex, type of disability, sport, BID model, body segment, limb dominance (Table 2), details of BID, and the way of applying it (Table 3). The main results were collected from each study.

\section{Ethical approval}

The conducted research is not related to either human or animal use.

\section{Results}

The research identified 981 articles. With the first search, 744 papers were excluded because they were duplicates; the remaining 237 were kept for the reading of the titles and abstracts. After the reading, 208 articles were excluded because they did not meet the defined selection criteria; the remaining 29 papers were to be read entirely, and, finally, 10 were included in the systematic review (Figure 1).

\section{Characterization of the studies}

Five studies were accomplished in Brazil [32-36], 2 in the Netherlands [37, 38], 1 in the United States [39], 1 in Poland [25], and 1 in New Zealand [40]. The total number of participants in the 10 studies was 219 , with 149 being para-athletes; the size of the sample ranged from 4 to 42 subjects. Four of the studies indicated the subjects' sex; in these papers, all participants were men (98 men among the 149 para-athletes) [33-35, 39]. The remaining 6 studies, which included 51 participants, did not present clear sex difference numbers. Among the 149 participants, the disability types included spinal cord injury (SCI) $(n=62)$, cerebral palsy (CP) $(n=30)$,
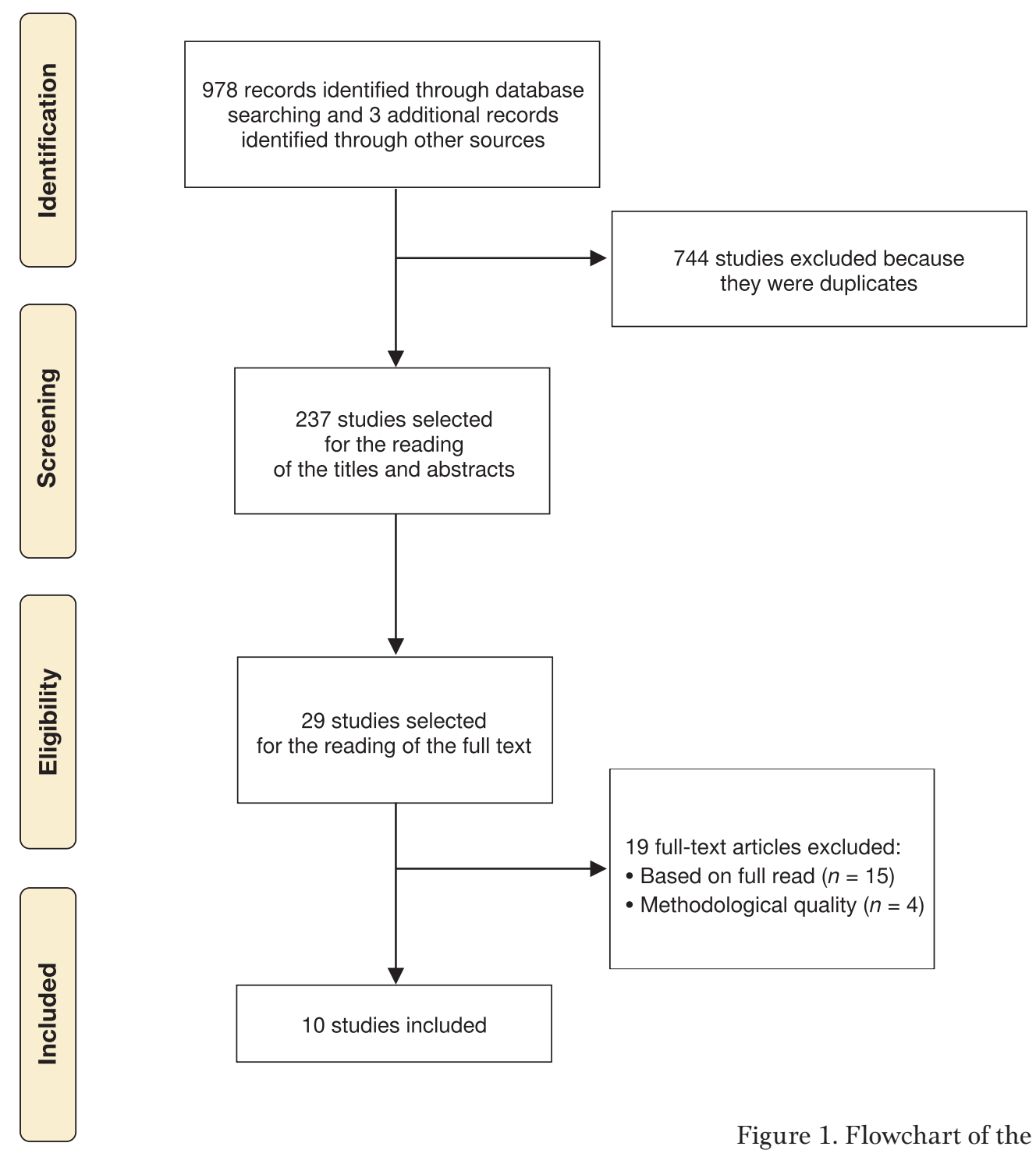

Figure 1. Flowchart of the study phases 
amputation (AMP) $(n=20)$, poliomyelitis sequelae (polio) $(n=16)$, spinal bifida (SB) $(n=7)$, arthrogryposis (Art) $(n=4)$, congenital deformity (CD) $(n=4)$, and visual impairment (VI) $(n=6)$. The participants were Paralympians of 6 different sports: athletics $(n=13)$, cycling $(n=4)$, football $(n=20)$, wheelchair basketball $(n=94)$, swimming $(n=1)$, and wheelchair rugby $(n=17)$.

The most often used BID (6 studies) was the Biodex Medical System 3 Pro (USA) [27, 32-34, 37, 39]. Two studies applied the Biodex System 4 Pro [33, 34], and 2 studies did not provide information about the Biodex system used [38, 40]. BID measurements were performed for a variety of joints or body segments in the included studies: for the knee in 4 studies [32, 35, 37, 38 ], for the elbow in 2 studies [36, 39], for the shoulder in 2 studies [25, 40], and for the trunk in 2 studies $[33,34]$. Table 2 presents a more detailed characterization of the articles. All details of the methods applied by the Biodex system in the studies, such as warm-up, position, range of motion, mode, velocity, repetitions, and outcomes (unit), are presented in Table 3.

\section{Discussion}

This systematic review gives an overview of studies investigating the interest of scientists in applying BID in Paralympic athletes. The quality of evidence of the analysed articles was measured. Five studies out of the 10 papers included in our systematic review presented a high risk of bias, so data from these articles should be examined with caution. For those using BID to evaluate para-athletes, we suggest referring to data from articles with a low risk of bias, with a similar experimental method. Even though, the papers with a low risk of bias unfitted in some items. It is significant to examine how the pointed items might affect data before using them as a reference. The reliability of BID methods was not

Table 1. Methodological quality of the included studies

\begin{tabular}{|c|c|c|c|c|c|c|c|c|c|c|c|c|c|c|c|c|}
\hline \multirow{2}{*}{ Study } & \multicolumn{15}{|c|}{ Items } & \multirow{2}{*}{$\begin{array}{l}\text { Total } \\
\text { of } n / u n\end{array}$} \\
\hline & 1 & 2 & 3 & 4 & 5 & 6 & 7 & 8 & 9 & 10 & 11 & 12 & 13 & 14 & 15 & \\
\hline Machado et al. (2018) [36] & $\mathrm{n}$ & $\mathrm{n}$ & un & $\mathrm{y}$ & $\mathrm{y}$ & $\mathrm{n}$ & $\mathrm{y}$ & $\mathrm{y}$ & $\mathrm{n}$ & $\mathrm{n}$ & un & $\mathrm{n}$ & $\mathrm{n}$ & $\mathrm{y}$ & un & 10 \\
\hline Antunes et al. (2017) [35] & $\mathrm{y}$ & $\mathrm{y}$ & un & $\mathrm{y}$ & $\mathrm{y}$ & un & $\mathrm{y}$ & $\mathrm{y}$ & $\mathrm{n}$ & $\mathrm{y}$ & $\mathrm{y}$ & $\mathrm{y}$ & un & $\mathrm{y}$ & na & $4 \dagger$ \\
\hline Santos et al. (2017) [34] & $\mathrm{y}$ & $\mathrm{y}$ & $\mathrm{y}$ & $\mathrm{y}$ & $\mathrm{y}$ & $\mathrm{y}$ & $\mathrm{n}$ & $\mathrm{y}$ & un & $\mathrm{y}$ & $\mathrm{y}$ & un & $\mathrm{y}$ & $\mathrm{y}$ & $\mathrm{y}$ & $3 \dagger$ \\
\hline Santos et al. (2016) [33] & $\mathrm{y}$ & $\mathrm{y}$ & $\mathrm{y}$ & $\mathrm{y}$ & $\mathrm{y}$ & $\mathrm{n}$ & $\mathrm{n}$ & $\mathrm{y}$ & $\mathrm{n}$ & $\mathrm{y}$ & $\mathrm{y}$ & un & un & $\mathrm{y}$ & $\mathrm{y}$ & 5 \\
\hline Silva et al. (2015) [32] & un & $\mathrm{n}$ & un & $\mathrm{y}$ & $\mathrm{y}$ & $\mathrm{n}$ & $\mathrm{y}$ & $\mathrm{y}$ & un & $\mathrm{n}$ & $\mathrm{y}$ & $\mathrm{n}$ & $\mathrm{n}$ & $\mathrm{y}$ & $\mathrm{y}$ & 8 \\
\hline De Groot et al. (2012) [37] & $\mathrm{y}$ & $\mathrm{y}$ & $\mathrm{y}$ & $\mathrm{y}$ & $\mathrm{y}$ & un & $\mathrm{y}$ & $\mathrm{n}$ & $\mathrm{y}$ & $\mathrm{n}$ & $\mathrm{y}$ & $\mathrm{y}$ & un & $\mathrm{y}$ & $\mathrm{y}$ & $4 \dagger$ \\
\hline De Groot et al. (2012) [38] & $\mathrm{y}$ & $\mathrm{y}$ & $\mathrm{n}$ & $\mathrm{y}$ & $\mathrm{y}$ & $\mathrm{y}$ & $\mathrm{y}$ & $\mathrm{y}$ & $\mathrm{y}$ & $\mathrm{n}$ & $\mathrm{y}$ & $\mathrm{y}$ & $\mathrm{y}$ & $\mathrm{y}$ & $\mathrm{y}$ & $2 \dagger$ \\
\hline Uzun et al. (2012) [39] & $\mathrm{y}$ & $\mathrm{y}$ & $\mathrm{n}$ & $\mathrm{y}$ & un & $\mathrm{n}$ & $\mathrm{y}$ & $\mathrm{y}$ & $\mathrm{y}$ & $\mathrm{y}$ & $\mathrm{y}$ & $\mathrm{y}$ & un & $\mathrm{y}$ & $\mathrm{y}$ & $4 \dagger$ \\
\hline Tabęcki et al. (2009) [25] & $\mathrm{n}$ & un & $\mathrm{n}$ & $\mathrm{n}$ & $\mathrm{n}$ & un & $\mathrm{y}$ & $\mathrm{n}$ & $\mathrm{n}$ & $\mathrm{n}$ & $\mathrm{y}$ & un & $\mathrm{n}$ & $\mathrm{y}$ & $\mathrm{n}$ & 12 \\
\hline Miyahara et al. (1998) [40] & $\mathrm{n}$ & $\mathrm{y}$ & $\mathrm{n}$ & $\mathrm{y}$ & $\mathrm{y}$ & un & $\mathrm{n}$ & un & $\mathrm{y}$ & $\mathrm{y}$ & $\mathrm{y}$ & un & $\mathrm{y}$ & $\mathrm{y}$ & $\mathrm{y}$ & 6 \\
\hline
\end{tabular}

Items considered for rating:

1. Was the study population adequately described (i.e. sex, age, body mass, body height, kind of physical activity/ life style [sedentary, athlete, level of physical activity])?

2. Was the description of selection criteria presented?

3. Was there justification of appropriate sample size (through calculation or guidelines)?

4. Were warm-ups and familiarization protocol performed?

5. Were the type of muscle action (i.e. concentric and eccentric), sequence of action (i.e. concentric-concentric, concentric-eccentric, eccentric-eccentric), and velocity of movement described?

6. Was the order of tests (velocities and limbs) randomized or counterbalanced?

7. Was the limb dominance considered?

8. Was the standardization of positions, movements, and stabilization performed and properly described?

9. Did the participants receive the same encouragement during the test?

10. Was gravity correction considered?

11. Were the outcome measures clearly described?

12. Were data extracted from the isokinetic load range?

13. Were measures of reliability (e.g. intraclass correlation coefficients, standard error of measurement) presented?

14. Were the results clearly described? 15 . Were appropriate inferential statistics presented?

$\mathrm{n}$ - no, y - yes, na - not applied, un - unclear

$\dagger$ studies with a low risk of bias 
Table 2. Characteristics of the studies included

\begin{tabular}{|c|c|c|c|c|c|c|c|c|}
\hline $\begin{array}{l}\text { Author, year, country, } \\
\text { aim of study }\end{array}$ & $\begin{array}{c}\text { Total } \\
\text { sample } \\
\text { and sex }\end{array}$ & $\begin{array}{l}\text { Para- } \\
\text { athletes }\end{array}$ & $\begin{array}{c}\text { Age (years) } \\
M \pm S D \\
\text { or range }\end{array}$ & Disability & Sport & $\begin{array}{l}\text { Biodex } \\
\text { model }\end{array}$ & $\begin{array}{l}\text { Body } \\
\text { segment }\end{array}$ & Limb \\
\hline $\begin{array}{l}\text { Machado et al. [36] } \\
2018 \\
\text { Brazil } \\
\text { To investigate athletes' peak } \\
\text { torque and fatigue index } \\
\text { variables in actions related } \\
\text { to wheelchair sprinting }\end{array}$ & $6 \mathrm{ND}$ & $6 \mathrm{ND}$ & $30.3 \pm 6.6$ & SCI & WR & System 4 & Elbow & Both \\
\hline
\end{tabular}

\begin{tabular}{llllllllll}
\hline Antunes et al. [35] & $4 \mathrm{M}$ & $4 \mathrm{M}$ & $18-27$ & CP & A & System 4 & Knee & Both
\end{tabular}

2017

Brazil

To assess muscle power, muscular imbalance, and asymmetry in sprinters with $\mathrm{CP}$

\begin{tabular}{|c|c|c|c|c|c|}
\hline $\begin{array}{l}\text { Santos et al. [34] } \\
2017 \\
\text { Brazil }\end{array}$ & $42 \mathrm{M}$ & $42 \mathrm{M}$ & $28.3 \pm 7.6$ & $\begin{array}{c}\text { SCI (17), AMP (10), } \\
\text { polio (8), SB (4), } \\
\text { Art (2), CP (1) }\end{array}$ & WB \\
\hline
\end{tabular}

To identify differences in trunk muscle strength and balance among various classes of wheelchair basketball players and to determine if trunk muscle strength and balance correlate with the current observation-based classification

\begin{tabular}{lcccc}
\hline $\begin{array}{l}\text { Santos et al. [33] } \\
\begin{array}{l}2016 \\
\text { Brazil }\end{array} \\
\text { To identify quantitative } \\
\text { measures of trunk muscle } \\
\text { strength and correlate them } \\
\text { with the wheelchair basketball } \\
\text { players' classification }\end{array}$ & $\begin{array}{c}\text { SCI (17), AMP (10), } \\
\text { polio (8), SB (3), }\end{array}$ & Art (2), CD (1), CP (1) & \\
\end{tabular}

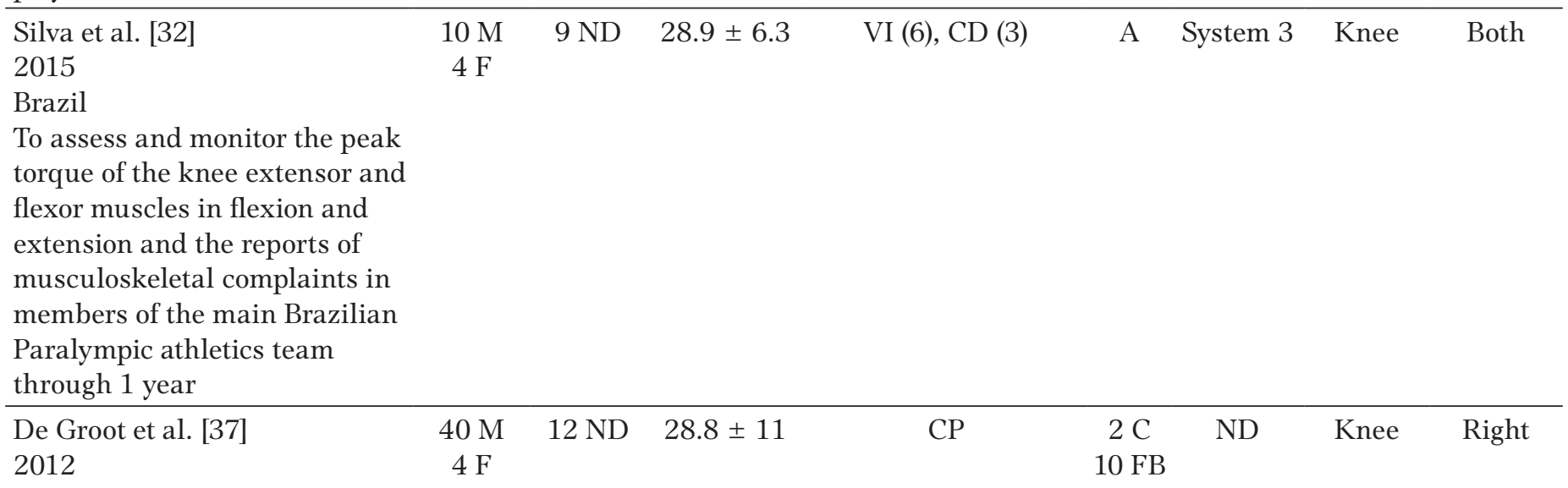

The Netherlands

To compare muscle strength, sprint power, and maximal aerobic capacity, as well as establish correlations between these variables in adults with and without $\mathrm{CP}$ 


\section{HUMAN MOVEMENT}

S. Ahmadi, M.C. Uchida, Isokinetic dynamometers and Paralympics

\begin{tabular}{|c|c|c|c|c|c|c|c|c|}
\hline $\begin{array}{l}\text { De Groot et al. [38] } \\
2012 \\
\text { The Netherlands } \\
\text { To analyse the feasibility } \\
\text { and reliability of the tests used } \\
\text { to determine muscle strength, } \\
\text { sprint power, and aerobic } \\
\text { capacity in athletes and } \\
\text { non-athletes with CP }\end{array}$ & $\begin{array}{c}16 \mathrm{M} \\
4 \mathrm{~F}\end{array}$ & $12 \mathrm{ND}$ & $18-49$ & $\mathrm{CP}$ & $\begin{array}{c}2 \mathrm{C} \\
10 \mathrm{FB}\end{array}$ & System 3 & Knee & Both \\
\hline $\begin{array}{l}\text { Uzun et al. [39] } \\
2012 \\
\text { USA } \\
\text { To investigate muscular } \\
\text { endurance and fatigue in } \\
\text { wheelchair basketball players } \\
\text { with SCI by using surface } \\
\text { electromyography and maximal } \\
\text { torque values }\end{array}$ & $35 \mathrm{M}$ & $10 \mathrm{M}$ & $29.6 \pm 6.4$ & SCI & $\begin{array}{c}10 \\
W B\end{array}$ & System 3 & Elbow & Dominant \\
\hline $\begin{array}{l}\text { Tabęcki et al. [25] } \\
2009 \\
\text { Poland } \\
\text { To assess the effects of strength } \\
\text { training on the physical } \\
\text { capacities of disabled persons } \\
\text { with cervical spine injuries }\end{array}$ & $4 \mathrm{ND}$ & $4 \mathrm{ND}$ & ND & SCI & $\begin{array}{c}1 \mathrm{~S} \\
3 \mathrm{WR}\end{array}$ & System 3 & Shoulder & Both \\
\hline $\begin{array}{l}\text { Miyahara et al. [40] } \\
1998 \\
\text { New Zealand } \\
\text { To examine the relationship of } \\
\text { shoulder pain to demographic } \\
\text { details, isokinetic strength, } \\
\text { and muscle balance in } 8 \text { elite } \\
\text { quadriplegic rugby players }\end{array}$ & $8 \mathrm{ND}$ & $8 \mathrm{ND}$ & $26.8 \pm 5$ & SCI & WR & ND & Shoulder & Both \\
\hline
\end{tabular}

A - athletics, AMP - amputation, Art - arthrogryposis, C - cycling, CD - congenital deformity, CP - cerebral palsy, F - female, FB - football, M - male, ND - not described, polio - poliomyelitis sequelae, S - swimming, SB - spinal bifida, SCI - spinal cord injury, VI - visual impairment, WB - wheelchair basketball, WR - wheelchair rugby

Table 3. Methods of using Biodex in the included studies

\begin{tabular}{|c|c|c|c|c|}
\hline Study & Warm-up & Position; ROM & $\begin{array}{l}\text { Mode; velocity; } \\
\text { repetitions }\end{array}$ & $\begin{array}{l}\text { Outcomes } \\
\text { (unit) }\end{array}$ \\
\hline $\begin{array}{l}\text { Machado et al. } \\
\text { (2018) [36] }\end{array}$ & $\begin{array}{l}5 \text { repetitions } \\
\text { of concentric action } \\
\text { at } 210 \% \mathrm{~s}\end{array}$ & $\begin{array}{l}\text { The seat was at } 0^{\circ} \text { rotation and } 85^{\circ} \\
\text { slope and the dynamometer at } 0^{\circ} \\
\text { rotation and } 15^{\circ} \text { slope; ND }\end{array}$ & $\begin{array}{l}\text { Concentric; } 210 \% \text {, } \\
300 \% \text { s, and } 300 \% \text {; } \\
5,15 \text {, and } 30 \\
\text { repetitions }\end{array}$ & $\begin{array}{l}\text { PT (Nm) } \\
\text { and FI (\%) }\end{array}$ \\
\hline $\begin{array}{l}\text { Antunes et al. } \\
(2017) \text { [35] }\end{array}$ & $\begin{array}{l}20 \text { knee flexion-extension } \\
\text { concentric submaximal } \\
\text { repetitions at } 120 \% \mathrm{~s}\end{array}$ & $\begin{array}{l}\text { Manufacturer's recommendations; } \\
70^{\circ}\left(30-100^{\circ} \text {, considering } 0^{\circ}=\text { total }\right. \\
\text { knee extension) }\end{array}$ & $\begin{array}{l}\text { Concentric/concentric; } \\
60 \% \text { s, } 120 \% \text { s, and } \\
180 \% \text { s; } 5 \text { repetitions } \\
\text { and eccentric reactive; } \\
60 \% \text { s and } 120 \% \text { s; } \\
5 \text { repetitions }\end{array}$ & PT (Nm) \\
\hline
\end{tabular}


Santos et al. The muscles of their (2017) [34] lower back were stretched for a few minutes
The subject was seated on the 'dual position back Ex/Flex attachment' of the Biodex dynamometer with the trunk positioned at $90^{\circ}$ relative to the thigh segments and with the knees flexed at ca. $45^{\circ}$ relative to the shank segments; the position of the subject was adjusted so that the trunk was aligned at an angle of $-15^{\circ}$ for flexor strength testing and $+15^{\circ}$ for extensor strength testing in relation to the vertical position $\begin{array}{ll}\text { Santos et al. } & \text { Undergone prior spinal } \\ \text { (2016) [33] } & \text { joint warm-up }\end{array}$
The trunk was at $90^{\circ}$ in relation to the femur and the knees were flexed at $45^{\circ}$ in relation to the lower legs; limited to $-15^{\circ}$ of extension and $15^{\circ}$ of flexion
Flexion/extension; ND; PT (Nm) 5 and 5 repetitions

\section{Flexion/extension; $\quad$ PT $(\mathrm{Nm})$ and ND; 10 repetitions $\quad$ TR (\%)}

\begin{tabular}{|c|c|c|}
\hline $\begin{array}{l}\text { The knees at } 90^{\circ} \text { flexion and the } \\
\text { resistance was distally applied to the } \\
\text { ankle joint } 5 \mathrm{~cm} \text { above the medial } \\
\text { malleolus; } 90^{\circ} \text { (between full knee } \\
\text { extension and } 90^{\circ} \text { flexion) }\end{array}$ & $\begin{array}{l}\text { Concentric/concentric } \\
\text { (flexion/extension); } \\
60,180 \text {, and } 300 \% \text { s; } \\
5,10 \text {, and } 15 \text { repetitions }\end{array}$ & PT (Nm) \\
\hline
\end{tabular}

Silva et al.

A cycle ergometer at $75 \mathrm{~W}$ and constant speed of $20 \mathrm{~km} / \mathrm{h}$ for 5 minutes

The hip angle ranged from $90^{\circ}$ to $110^{\circ}$ and the centre of the knee joint aligned with the dynamometer centre of rotation; $70^{\circ}\left(90-160^{\circ}\right)$
De Groot et al. ND

(2012) [37]
The hip angle ranged from $90^{\circ}$ to $110^{\circ}$ and the centre of the knee joint aligned with the dynamometer centre of rotation; ND

\begin{tabular}{lll}
\hline $\begin{array}{l}\text { De Groot et al. } \\
\text { (2012) [38] }\end{array}$ & $\begin{array}{l}\text { The participants } \\
\text { performed } 1 \text { isometric } \\
\text { exertion for extension } \\
\text { and flexion }\end{array}$ & $\begin{array}{l}\text { The hip angle ranged from } 90^{\circ} \text { to } 110^{\circ} \\
\text { and the centre of the knee joint aligned } \\
\text { with the dynamometer centre of rotation; } \\
\text { ND }\end{array}$ \\
\hline $\begin{array}{l}\text { Uzun et al. } \\
(2012)[39]\end{array}$ & ND & $\begin{array}{l}\text { The arm was maintained in the horizontal } \\
\text { plane to eliminate the effects of gravity, } \\
\text { with an elbow angle of } 90^{\circ} \text { flexion, the } \\
\text { hand was in a semi-pronated position, } \\
\text { subjects gripped a rigid handle and rested } \\
\text { their forearm on a padded support; ND }\end{array}$ \\
\hline
\end{tabular}
Flexion/extension;
$60 \%$ s; 3 repetitions

PT (Nm)

Flexion/extension; PT (Nm) $60 \%$; 3 repetitions

ND PT (Nm)

\begin{tabular}{|c|c|c|c|c|}
\hline $\begin{array}{l}\text { Tabęcki et al. } \\
\text { (2009) [25] }\end{array}$ & ND & ND & $\begin{array}{l}\text { Flexion/extension; } \\
30 \% \text { s and } 300 \% \text { s; ND }\end{array}$ & $\begin{array}{l}\mathrm{PT}(\mathrm{Nm}) \text { and } \\
\text { power }(\mathrm{W})\end{array}$ \\
\hline $\begin{array}{l}\text { Miyahara et al. } \\
\text { (1998) [40] }\end{array}$ & $\begin{array}{l}\text { Given } 3-5 \text { submaximal } \\
\text { trials and } 1 \text { maximal } \\
\text { familiarization trial }\end{array}$ & ND & $\begin{array}{l}\text { Concentric/concentric } \\
\text { (abduction/adduction } \\
\text { and internal/external } \\
\text { rotation); } 60 \% \text { s and } \\
180 \% \text { s ND }\end{array}$ & PT (Nm) \\
\hline
\end{tabular}

FI - fatigue index, ND - not described, PT - peak torque, ROM - range of motion, TR - torque ratio

defined in 7 articles $\left(13^{\text {th }}\right.$ item). There is a scarcity of articles tracking test-retest reliability for evaluations of para-athletes. Differences in the determined reliability among articles might be due to differences in BID methods and participants. Additionally, future studies may examine tracking para-athletes to present reliability evaluations specifically related to their methods. This is necessary for assigning the internal con- sistency of the method and testing the effect of interventions.

BID was introduced in 1990; in the recent 3 decades, just 10 papers have been published about BID applied in Paralympic sports. Although BID is a gold standard for biomechanical data measurement [41], the small number of studies in Paralympic fields shows a lack of scientists' interest to use the method in their 
studies. Among the included studies, 50\% were performed in Brazil in years 2015-2018 [32-36], which indicates a tendency of Brazilian researchers to investigate this topic to a higher degree than in the case of other countries, particularly in the recent years.

Page et al. [42] found that male and female Paralympic athletes were not significantly different in their sports orientations and differed very little in their mean scores on the scales. On the other hand, the sex of the subjects who participated in the included studies was not always indicated but there seemed to be more men than women. This suggests a deficiency of studies in the field of BID applied in women as compared with men in Paralympic sports.

The criteria of our systematic review for carrying out a meta-analysis were not paired. Particular experimental procedures for BID assessments were provided by the manufacturers. However, we observed using some experimental methods (i.e. warm-up, positions, range of motion, types of mode, the velocity of movement, repetitions, etc.) in the included studies. Therefore, comparisons among studies should be made with caution. Generally, the lack of standardization in the experimental methods precludes pooling data for analyses.

An important limiting factor in this study was the selection of studies that only used BID, whereas other isokinetic dynamometers (i.e. Cybex or Kin-Com) were probably applied in many studies performed among Paralympic athletes. We recommend that future studies measure and report differences of the conclusions that may present a more comprehensive understanding of isokinetic exercises for para-athletes.

\section{Conclusions}

This systematic review revealed the characteristics and methodologies of several studies applying BID in the Paralympic athletes' population. Data from all included studies were summarized. BID was introduced about 3 decades ago and just 10 papers were published about its usage in Paralympic sports. However, BID is a gold standard, reliable and valid instrument to measure human joint function. Future well-conducted studies aiming to utilize BID in Paralympic athletes are encouraged.

\section{Disclosure statement}

No author has any financial interest or received any financial benefit from this research.

\section{Conflict of interest}

The authors state no conflict of interest.

\section{References}

1. Hislop HJ, Perrine JJ. The isokinetic concept of exercise. Phys Ther. 1967;47(2):114-117; doi: 10.1093/ptj/47.2.114.

2. Li RC, Jasiewicz JM, Middleton J, Condie P, Barriskill A, Hebnes $\mathrm{H}$, et al. The development, validity, and reliability of a manual muscle testing device with integrated limb position sensors. Arch Phys Med Rehabil. 2006;87(3):411-417; doi: 10.1016/j.apmr.2005.11.011.

3. Molnar GE, Alexander J. Development of quantitative standards for muscle strength in children. Arch Phys Med Rehabil. 1974;55(11):490-493.

4. Goslin BR, Charteris J. Isokinetic dynamometry: normative data for clinical use in lower extremity (knee) cases. Scand J Rehabil Med. 1979;11(3):105-109.

5. Wyatt MP, Edwards AM. Comparison of quadriceps and hamstring torque values during isokinetic exercise. J Orthop Sports Phys Ther. 1981;3(2):48-56; doi: 10.2519/jospt.1981.3.2.48.

6. El-Zayat BF, Efe T, Heidrich A, Wolf U, Timmesfeld N, Heyse TJ, et al. Objective assessment of shoulder mobility with a new 3D gyroscope - a validation study. BMC Musculoskelet Disord. 2011;12:168; doi: 10.1186/ 1471-2474-12-168.

7. Seto JL, Brewster CE, Lombardo SJ, Tibone JE. Rehabilitation of the knee after anterior cruciate ligament reconstruction. J Orthop Sports Phys Ther. 1989;11(1): 8-18; doi: 10.2519/jospt.1989.11.1.8.

8. DiNubile NA. Strength training. Clin Sports Med. 1991; 10(1):33-62; doi: 10.1016/S0278-5919(20)30657-8.

9. Martin A, Martin L, Morlon B. Theoretical and experimental behaviour of the muscle viscosity coefficient during maximal concentric actions. Eur J Appl Physiol Occup Physiol. 1994;69(6):539-544; doi: 10.1007/ BF00239872.

10. Cheng AJ, Rice CL. Fatigue and recovery of power and isometric torque following isotonic knee extensions. J Appl Physiol. 2005;99(4):1446-1452; doi: 10.1152/ japplphysiol.00452.2005.

11. McCleary RW, Andersen JC. Test-retest reliability of reciprocal isokinetic knee extension and flexion peak torque measurements. J Athl Train. 1992;27(4):362-365.

12. Frisiello S, Gazaille A, O’Halloran J, Palmer ML, Waugh D. Test-retest reliability of eccentric peak torque values for shoulder medial and lateral rotation using the Biodex isokinetic dynamometer. J Orthop Sports Phys Ther. 1994;19(6):341-344; doi: 10.2519/jospt.1994. 19.6.341.

13. Drouin JM, Valovich-Mc Leod TC, Shultz SJ, Gansneder BM, Perrin DH. Reliability and validity of the Biodex System 3 pro isokinetic dynamometer velocity, torque and position measurements. Eur J Appl Physiol. 2004;91(1):22-29; doi: 10.1007/s00421-003-0933-0.

14. Lambert CP, Archer RL, Evans WJ. Muscle strength and fatigue during isokinetic exercise in individuals with multiple sclerosis. Med Sci Sports Exerc. 2001;33(10): 1613-1619; doi: 10.1097/00005768-200110000-00001. 
15. Bhambhani Y. Physiology of wheelchair racing in athletes with spinal cord injury. Sports Med. 2002;32(1): 23-51; doi: 10.2165/00007256-200232010-00002.

16. Goosey-Tolfrey VL, Tolfrey K. The multi-stage fitness test as a predictor of endurance fitness in wheelchair athletes. J Sports Sci. 2008;26(5):511-517; doi: 10.1080/ 02640410701624531.

17. Bernardi M, Guerra E, Di Giacinto B, Di Cesare A, Castellano V, Bhambhani Y. Field evaluation of Paralympic athletes in selected sports: implications for training. Med Sci Sports Exerc. 2010;42(6):1200-1208; doi: 10.1249/MSS.0b013e3181c67d82.

18. Vanlandewijck Y, Theisen D, Daly D. Wheelchair propulsion biomechanics: implications for wheelchair sports. Sports Med. 2001;31(5):339-367; doi: 10.2165/00007 256-200131050-00005.

19. Dubowsky SR, Sisto SA, Langrana NA. Comparison of kinematics, kinetics, and EMG throughout wheelchair propulsion in able-bodied and persons with paraplegia: an integrative approach. J Biomech Eng. 2009;131(2): 021015; doi: 10.1115/1.2900726.

20. Nyland J, Robinson K, Caborn D, Knapp E, Brosky T. Shoulder rotator torque and wheelchair dependence differences of National Wheelchair Basketball Association players. Arch Phys Med Rehabil. 1997;78(4): 358-363; doi: 10.1016/s0003-9993(97)90226-4.

21. Ambrosio F, Boninger ML, Souza AL, Fitzgerald SG, Koontz AM, Cooper RA. Biomechanics and strength of manual wheelchair users. J Spinal Cord Med. 2005; 28(5):407-414; doi: 10.1080/10790268.2005.11753840.

22. Bjerkefors A, Thorstensson A. Effects of kayak ergometer training on motor performance in paraplegics. Int J Sports Med. 2006;27(10):824-829; doi: 10.1055/s2005-872970.

23. Wang YT, Chen S, Limroongreungrat W, Change L-S. Contributions of selected fundamental factors to wheelchair basketball performance. Med Sci Sports Exerc. 2005;37(1):130-137; doi: 10.1249/01.mss.0000150076. 36706.b2.

24. Ahmadi S, Uchida MC, Gutierrez GL. Physical performance tests in male and female sitting volleyball players: pilot study of Brazilian national team. Asian J Sports Med. 2019;10(2):e85984; doi: 10.5812/asjsm. 85984.

25. Tabęcki R, Kosmol A, Mastalerz A. Effects of strength training on physical capacities of the disabled with cervical spine injuries. Hum Mov. 2009;10(2):126-129; doi: 10.2478/v10038-009-0020-4.

26. Tweedy SM, Vanlandewijck YC. International Paralympic Committee position stand - background and scientific principles of classification in Paralympic sport. Br J Sports Med. 2011;45(4):259-269; doi: 10.1136/ bjsm.2009.065060.

27. Tsiros MD, Grimshaw PN, Shield AJ, Buckley JD. The Biodex isokinetic dynamometer for knee strength assessment in children: advantages and limitations. Work. 2011;39(2):161-167; doi: 10.3233/WOR-2011-1162.
28. Ahmadi S, Gutierrez GL, Uchida MC. Asymmetry in glenohumeral muscle strength of sitting volleyball players: an isokinetic profile of shoulder rotations strength. J Sports Med Phys Fitness. 2020;60(3):395-401; doi: 10.23736/S0022-4707.19.10144-2.

29. De Castro MP, Ruschel C, Santos GM, Ferreira T, Pierri CAA, Roesler H. Isokinetic hip muscle strength: a systematic review of normative data. Sports Biomech. 2020;19(1):26-54; doi: 10.1080/14763141.2018.1464594.

30. Whiting P, Rutjes AWS, Reitsma JB, Bossuyt PMM, Kleijnen J. The development of QUADAS: a tool for the quality assessment of studies of diagnostic accuracy included in systematic reviews. BMC Med Res Methodol. 2003;3:25; doi: 10.1186/1471-2288-3-25.

31. Downs SH, Black N. The feasibility of creating a checklist for the assessment of the methodological quality both of randomised and non-randomised studies of health care interventions. J Epidemiol Community Health. 1998;52(6):377-384; doi: 10.1136/jech.52.6.377.

32. Silva A, Zanca G, Alves ES, de Aquino Lemos V, Gávea $S A$, Winckler $C$, et al. Isokinetic assessment and musculoskeletal complaints in Paralympic athletes: a longitudinal study. Am J Phys Med Rehabil. 2015; 94(10):768-774; doi: 10.1097/PHM.0000000000000 244.

33. Santos SS, Alonso AC, Greve JMD. Quantitative evaluation of trunk muscle strength in wheelchair basketball players. Motriz. 2016;22(2):69-72; doi: 10.1590/ S1980-6574201600020009.

34. Santos SS, Krishnan C, Alonso AS, Greve JMD. Trunk function correlates positively with wheelchair basketball player classification. Am J Phys Med Rehabil. 2017;96(2):101-108; doi: 10.1097/PHM.0000000000 000548 .

35. Antunes D, Rossato M, Kons RL, Sakugawa RL, Fischer G. Neuromuscular features in sprinters with cerebral palsy: case studies based on Paralympic classification. JExerc Rehabil. 2017;13(6):716-721; doi: 10.12965/ jer.1735112.556.

36. Machado F, Correia RF, Ribeiro AN, Neto SRS, Vieira IB, Gorla JI. Isokinetic peak of torque and fatigue index in simulated wheelchair propulsion in elite wheelchair rugby players. Man Ther Posturology Rehabil J. 2018;16: 564; doi: 10.17784/mtprehabjournal.2018.16.564.

37. De Groot S, Dallmeijer AJ, Bessems PJC, Lamberts ML, van der Woude LHV, Janssen TWJ. Comparison of muscle strength, sprint power and aerobic capacity in adults with and without cerebral palsy. J Rehabil Med. 2012;44(11):932-938; doi: 10.2340/16501977-1037.

38. De Groot S, Janssen TWJ, Evers M, Van der Luijt P, Nienhuys KNG, Dallmeijer AJ. Feasibility and reliability of measuring strength, sprint power, and aerobic capacity in athletes and non-athletes with cerebral palsy. Dev Med Child Neurol. 2012;54(7):647-653; doi: 10.1111/j.1469-8749.2012.04261.x.

39. Uzun S, Pourmoghaddam A, Hieronymus M, Thrasher TA. Evaluation of muscle fatigue of wheelchair bas- 


\section{HUMAN MOVEMENT}

S. Ahmadi, M.C. Uchida, Isokinetic dynamometers and Paralympics

ketball players with spinal cord injury using recurrence quantification analysis of surface EMG. Eur J Appl Physiol. 2012;112(11):3847-3857; doi: 10.1007/ s00421-012-2358-0.

40. Miyahara M, Sleivert GG, Gerrard DF. The relationship of strength and muscle balance to shoulder pain and impingement syndrome in elite quadriplegic wheelchair rugby players. Int J Sports Med. 1998;19(3):210214; doi: 10.1055/s-2007-971906.

41. Martin HJ, Yule V, Syddall HE, Dennison EM, Cooper C, Aihie Sayer A. Is hand-held dynamometry useful for the measurement of quadriceps strength in older people? A comparison with the gold standard Biodex dynamometry. Gerontology. 2006;52(3):154-159; doi: 10.1159/000091824.

42. Page SJ, O’Connor EA, Wayda VK. Exploring competitive orientation in a group of athletes participating in the 1996 Paralympic trials. Percept Motor Skills. 2000; 91(2):491-502; doi: 10.2466/pms.2000.91.2.491. 